\title{
Alkalibacillus flavidus sp. nov., isolated from a marine solar saltern
}

\author{
Jung-Hoon Yoon, So-Jung Kang, Yong-Taek Jung, Mi-Hwa Lee \\ and Tae-Kwang Oh
}

Correspondence

Jung-Hoon Yoon

jhyoon@kribb.re.kr
Korea Research Institute of Bioscience and Biotechnology (KRIBB), PO Box 115, Yusong, Taejon, Republic of Korea

\begin{abstract}
A Gram-stain-positive, motile, rod-shaped bacterial strain, ISL-17 ${ }^{\top}$, was isolated from a marine solar saltern of the Yellow Sea, Korea, and its taxonomic position was investigated by means of a polyphasic study. Strain ISL-1 $7^{\top}$ grew optimally at $\mathrm{pH} 8.5-9.0$, at $37{ }^{\circ} \mathrm{C}$ and in the presence of approximately $10 \%(\mathrm{w} / \mathrm{v}) \mathrm{NaCl}$. It contained meso-diaminopimelic acid as the diagnostic diamino acid in the peptidoglycan, MK-7 as the predominant menaquinone and iso- $\mathrm{C}_{15: 0}$, anteiso- $\mathrm{C}_{15: 0}$ and iso- $\mathrm{C}_{16: 0}$ as the major fatty acids. The DNA G+C content was $48.1 \mathrm{~mol} \%$. Phylogenetic analysis based on $16 \mathrm{~S}$ rRNA gene sequences showed that strain $I S L-17^{\top}$ fell within the genus Alkalibacillus, clustering with Alkalibacillus salilacus $\mathrm{BH} 163^{\top}$ with a bootstrap resampling value of $100 \%$. Strain ISL-17 $7^{\top}$ exhibited $98.2 \% 16$ S rRNA gene sequence similarity to $A$. salilacus $\mathrm{BH} 163^{\top}$ and $95.8-96.5 \%$ similarity to the type strains of the other Alkalibacillus species. The mean DNA-DNA relatedness value between strain ISL-1 $7^{\top}$ and $A$. salilacus $\mathrm{KCTC} 3916^{\top}$ was $19 \%$. The phenotypic properties of strain ISL-17 ${ }^{\top}$, together with its phylogenetic and genetic distinctiveness, enable this strain to be differentiated from recognized Alkalibacillus species. On the basis of phenotypic, phylogenetic and genetic data, strain ISL-1 $7^{\top}$ represents a novel species within the genus Alkalibacillus, for which the name Alkalibacillus flavidus sp. nov. is proposed; the type strain is ISL-17 ${ }^{\top}\left(=\right.$ KCTC $13258^{\top}=$ CCUG $\left.56753^{\top}\right)$.
\end{abstract}

The genus Alkalibacillus was proposed by Jeon et al. (2005), who reclassified Bacillus haloalkaliphilus Fritze 1996 as Alkalibacillus haloalkaliphilus and described a novel species, Alkalibacillus salilacus. Subsequently, two more species, Alkalibacillus filiformis (Romano et al., 2005) and Alkalibacillus silvisoli (Usami et al., 2007), have been described. Members of the genus Alkalibacillus can be differentiated from those of phylogenetically related genera, i.e. Filobacillus and Tenuibacillus, on the basis of peptidoglycan type and 16S rRNA gene sequence similarity (Jeon et al., 2005). Members of the genus Alkalibacillus have been isolated from alkaline and highly saline mud, a salt lake, water of a mineral pool with gas bubbles and nonsaline surface soil (Jeon et al., 2005; Romano et al., 2005; Usami et al., 2007). In this study, the taxonomic characterization is reported of an Alkalibacillus-like bacterial strain, ISL $-17^{\mathrm{T}}$, isolated from a marine solar saltern in Korea.

Strain ISL-17 ${ }^{\mathrm{T}}$ was isolated from a marine solar saltern from the Yellow Sea, Korea, by means of the standard dilution plating technique at $30{ }^{\circ} \mathrm{C}$ on marine agar 2216 (MA; Difco) supplemented with 6\% (w/v) $\mathrm{NaCl}$ (total

The GenBank/EMBL/DDBJ accession number for the 16S rRNA gene sequence of strain ISL-17 ${ }^{\top}$ is EU874387.
$\mathrm{NaCl}$ concentration $7.945 \%$, w/v). Alkalibacillus salilacus KCTC $3916^{\mathrm{T}}$, which was used as a reference strain for DNA-DNA hybridization and fatty acid analysis, was obtained from the Korean Collection for Type Cultures. The morphological, physiological and biochemical characteristics of strain ISL- $17^{\mathrm{T}}$ were investigated using cells routinely cultivated on MA supplemented with $8 \%(\mathrm{w} / \mathrm{v})$ $\mathrm{NaCl}(8 \% \mathrm{NaCl} \mathrm{MA})$ at $37^{\circ} \mathrm{C}$. Cell morphology was examined by light microscopy (Nikon E600) and transmission electron microscopy. Flagellation was determined using a Philips CM-20 transmission electron microscope with cells from exponentially growing cultures; for this purpose, cells were negatively stained with $1 \%(\mathrm{w} / \mathrm{v})$ phosphotungstic acid and grids were examined after being air-dried. Growth under anaerobic conditions was determined after incubation in a Forma anaerobic chamber on $8 \% \mathrm{NaCl} \mathrm{MA}$ and on $8 \% \mathrm{NaCl} \mathrm{MA}$ supplemented with potassium nitrate $(0.1 \%, w / v)$, both of which had been prepared anaerobically under a nitrogen atmosphere. Growth in the absence of $\mathrm{NaCl}$ was investigated using trypticase soy broth prepared according to the formula of the Difco medium except that $\mathrm{NaCl}$ was omitted. Growth at $2.0-28.0 \%(\mathrm{w} / \mathrm{v}) \mathrm{NaCl}$ (in $1.0 \%$ increments) was investigated in marine broth 2216 (MB; Difco). The $\mathrm{pH}$ range for growth was determined in $\mathrm{MB}$ supplemented with $8 \%(w / v) ~ \mathrm{NaCl}(8 \% \mathrm{NaCl} \mathrm{MB})$ adjusted to $\mathrm{pH} 4.5-$ 
10.5 (at intervals of $0.5 \mathrm{pH}$ unit) by using sodium acetate/ acetic acid and $\mathrm{Na}_{2} \mathrm{CO}_{3}$ buffers. Growth at 4, 10, 20, 25, 28, $30,35,37,40,45,50,55$ and $60{ }^{\circ} \mathrm{C}$ was measured on $8 \%$ $\mathrm{NaCl} \mathrm{MA}$. Catalase and oxidase activities were determined as described by Cowan \& Steel (1965). Hydrolysis of casein, starch, hypoxanthine, tyrosine and xanthine was tested on $8 \% \mathrm{NaCl}$ MA using the substrate concentrations described by Cowan \& Steel (1965). Hydrolysis of aesculin, gelatin, Tweens 20, 40, 60 and 80 and urea and nitrate reduction were investigated as described previously (Lányí, 1987) with the modification that artificial seawater supplemented with $8 \%(\mathrm{w} / \mathrm{v}) \mathrm{NaCl}$ was used for preparation of media. The artificial seawater contained $\left(1^{-1}\right.$ distilled water $)$ $23.6 \mathrm{~g} \mathrm{NaCl}, 0.64 \mathrm{~g} \mathrm{KCl}, 4.53 \mathrm{~g} \mathrm{MgCl}_{2} .6 \mathrm{H}_{2} \mathrm{O}, 5.94 \mathrm{~g}$ $\mathrm{MgSO}_{4} \cdot 7 \mathrm{H}_{2} \mathrm{O}$ and $1.3 \mathrm{~g} \mathrm{CaCl}_{2} \cdot 2 \mathrm{H}_{2} \mathrm{O}$ (Bruns et al., 2001). $\mathrm{H}_{2} \mathrm{~S}$ production was tested as described previously (Bruns et al., 2001). Susceptibility to antibiotics was investigated on $8 \% \mathrm{NaCl} \mathrm{MA}$ by using antibiotic discs containing the following: polymyxin B (100 U), streptomycin $(50 \mu \mathrm{g})$, penicillin $\mathrm{G}(20 \mathrm{U})$, chloramphenicol $(100 \mu \mathrm{g})$, ampicillin $(10 \mu \mathrm{g})$, cephalothin $(30 \mu \mathrm{g})$, gentamicin $(30 \mu \mathrm{g})$, novobiocin $(5 \mu \mathrm{g})$, tetracycline $(30 \mu \mathrm{g})$, kanamycin $(30 \mu \mathrm{g})$, lincomycin $(15 \mu \mathrm{g})$, oleandomycin $(15 \mu \mathrm{g})$, neomycin $(30 \mu \mathrm{g})$ and carbenicillin $(100 \mu \mathrm{g})$. Acid production from carbohydrates was tested as described by Leifson (1963) with the modification that medium was supplemented with $8 \%(\mathrm{w} / \mathrm{v}) \mathrm{NaCl}$. Enzyme activities were determined by using the API ZYM system (bioMérieux).

Cell biomass for DNA extraction and for the analysis of the cell wall and isoprenoid quinones was obtained from cultures grown in $8 \% \mathrm{NaCl} \mathrm{MB}$ at $37{ }^{\circ} \mathrm{C}$. Chromosomal DNA was isolated and purified according to the method described by Yoon et al. (1996) except that RNase T1 was

Table 1. Differential characteristics of strain ISL $-17^{\top}$ and the type strains of other Alkalibacillus species

Strains: 1, ISL-17 ${ }^{\mathrm{T}}$; 2, A. salilacus BH163 ${ }^{\mathrm{T}}$ (data from Jeon et al., 2005; Usami et al., 2007); 3, A. haloalkaliphilus DSM 5271 ${ }^{\mathrm{T}}$ (Fritze, 1996; Usami

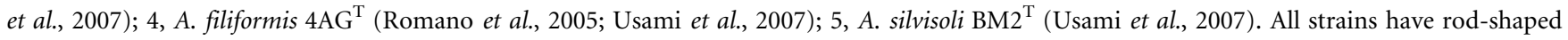
cells. +, Positive; -, negative; w, weakly positive; ND, no data available.

\begin{tabular}{|c|c|c|c|c|c|}
\hline Characteristic & 1 & 2 & 3 & 4 & 5 \\
\hline Gram stain & + & + & $+^{*}$ & + & + \\
\hline \multicolumn{6}{|c|}{$\mathrm{NaCl}$ concentration for growth (\%) } \\
\hline Range & $4.0-26.0$ & $5.0-20.0$ & $>0$ to 25.0 & $0-18.0$ & $5.0-25.0$ \\
\hline Optimum & 10.0 & $10.0-12.0$ & $5.0-10.0$ & 10.0 & $10.0-15.0$ \\
\hline Range & $5.5-9.5$ & $7.0-9.0$ & $>7$ to $>9.7$ & $7.0-10.0$ & $7.0-10.0$ \\
\hline Optimum & $8.5-9.0$ & 8.0 & 9.7 & 9.0 & $9.0-9.5$ \\
\hline \multicolumn{6}{|l|}{ Growth temperature $\left({ }^{\circ} \mathrm{C}\right)$} \\
\hline Range & 10 to $<60$ & $15-40$ & $<50$ & $15-45$ & $20-50$ \\
\hline Optimum & 37 & 30 & $30-37$ & 30 & $30-37$ \\
\hline Catalase & + & + & + & $\mathrm{w}$ & + \\
\hline Casein & - & - & $-/ \mathrm{w}$ & - & + \\
\hline Gelatin & - & - & + & + & + \\
\hline Starch & - & - & $\mathrm{w}$ & - & - \\
\hline \multicolumn{6}{|l|}{ Acid production from } \\
\hline L-Arabinose & - & + & ND & ND & ND \\
\hline D-Fructose & - & + & - & - & - \\
\hline D-Galactose & - & - & - & - & + \\
\hline Lactose & - & + & ND & ND & ND \\
\hline Maltose & + & - & - & - & + \\
\hline Trehalose & - & - & - & - & + \\
\hline D-Mannitol & - & - & - & - & + \\
\hline
\end{tabular}

${ }^{\star}$ Data from Fritze (1996); reported as Gram-stain-negative by Jeon et al. (2005) and Usami et al. (2007).

$\nmid \mathrm{C}$, Cream; CWH, creamy white; LY, light yellow; WH-T, white to transparent. 
used in combination with RNase A to minimize contamination with RNA. The 16S rRNA gene was amplified by PCR using two universal primers, 5'-GAGTTTGATCCTGGCTCAG-3' and 5' $^{\prime}$-AGAAAGGAGGTGATCCAGCC-3', as described previously (Yoon et al., 1998). Sequencing of the amplified 16S rRNA gene and phylogenetic analysis were performed as described by Yoon et al. (2003). The isomer type of the diamino acid in the cell-wall peptidoglycan was analysed using TLC according to the method described by Komagata \& Suzuki (1987). Isoprenoid quinones were analysed as described by Komagata \& Suzuki (1987) using reversed-phase HPLC and a YMC ODS-A $(250 \times 4.6 \mathrm{~mm})$ column. For cellular fatty acid analysis, cell mass of strain ISL- $17^{\mathrm{T}}$ was harvested from $8 \% \mathrm{NaCl} \mathrm{MA}$ after cultivation for 3 days at both 37 and $30{ }^{\circ} \mathrm{C}$, and cell mass of A. salilacus KCTC $3916^{\mathrm{T}}$ was harvested from $8 \% \mathrm{NaCl} \mathrm{MA}$ after cultivation for 3 days at $30{ }^{\circ} \mathrm{C}$. Fatty acids were extracted and fatty acid methyl esters were prepared according to the standard protocol of the MIDI/Hewlett Packard Microbial Identification System (Sasser, 1990). The DNA G + C content was determined by the method of Tamaoka \& Komagata (1984) with the modification that DNA was hydrolysed using nuclease P1 (Sigma) and the resultant nucleotides were analysed by reversed-phase HPLC. DNA-DNA hybridization was performed fluorometrically by the method of Ezaki et al. (1989) using photobiotin-labelled DNA probes and microdilution wells. Hybridization was performed with five replications for each sample. The highest and lowest values obtained in each sample were excluded and the means of the remaining three values are quoted as DNADNA relatedness values.

Morphological, cultural, physiological and biochemical characteristics of strain ISL- $17^{\mathrm{T}}$ are given in the species description and in Table 1. The almost-complete 16S rRNA gene sequence of strain ISL- $17^{\mathrm{T}}$ determined in this study comprised $1520 \mathrm{nt}$, representing approximately $96 \%$ of the
Escherichia coli 16S rRNA gene sequence. In the phylogenetic tree based on the neighbour-joining algorithm, strain ISL- $17^{\mathrm{T}}$ fell within the clade comprising Alkalibacillus species, particularly clustering with the type strain of $A$. salilacus at a bootstrap resampling value of $100 \%$ (Fig. 1). The same topology was also found in trees constructed using the maximum-likelihood and maximum-parsimony algorithms (Fig. 1). Strain ISL-17 $7^{\mathrm{T}}$ exhibited 16S rRNA gene sequence similarity values of $98.2 \%$ to A. salilacus $\mathrm{BH}_{163}{ }^{\mathrm{T}}$, $95.8-96.5 \%$ to type strains of the other Alkalibacillus species and less than $94.5 \%$ to other species used in the phylogenetic analysis.

Strain ISL- $17^{\mathrm{T}}$ had meso-diaminopimelic acid as the diagnostic diamino acid in the cell-wall peptidoglycan. The predominant menaquinone detected in strain ISL- $17^{\mathrm{T}}$ was MK-7 (at a peak area ratio of approximately 93\%). The cellular fatty acid profiles of strain ISL- $17^{\mathrm{T}}$ cultivated at two different temperatures are shown in Table 2, together with that of A. salilacus KCTC $3916^{\mathrm{T}}$, determined in this study. Strain ISL- $17^{\mathrm{T}}$ had large amounts of branched and straightchain fatty acids; the major components $(>10 \%$ of total fatty acids) were iso- $C_{15: 0}$, anteiso- $C_{15: 0}$ and iso- $C_{16: 0}$. The fatty acid profiles of strain ISL- $17^{\mathrm{T}}$ and A. salilacus KCTC $3916^{\mathrm{T}}$ were similar in that iso- $\mathrm{C}_{15: 0}$ and anteiso- $\mathrm{C}_{15: 0}$ are the major fatty acids, although there were differences in the proportions of some fatty acids, particularly iso- $\mathrm{C}_{16: 0}$ and anteiso- $\mathrm{C}_{17: 0}$, between the two strains (Table 1; Jeon et al., 2005). The fatty acid profiles of strain ISL- $17^{\mathrm{T}}$ and the other Alkalibacillus species were basically similar, although anteiso- $\mathrm{C}_{17: 0}$ is one of major components in A. filiformis or A. silvisoli, but not in strain ISL- $17^{\mathrm{T}}$, and iso- $\mathrm{C}_{16: 0}$ is one of major components in strain ISL-17 ${ }^{\mathrm{T}}$, but not in $A$. haloalkaliphilus, A. filiformis or A. silvisoli (Table 1; Jeon et al., 2005; Romano et al., 2005; Usami et al., 2007). The DNA $\mathrm{G}+\mathrm{C}$ content of strain ISL- $17^{\mathrm{T}}$ was $48.1 \mathrm{~mol} \%$, which is higher than those of other Alkalibacillus species (Table 1). Data obtained from these chemotaxonomic analyses sup-

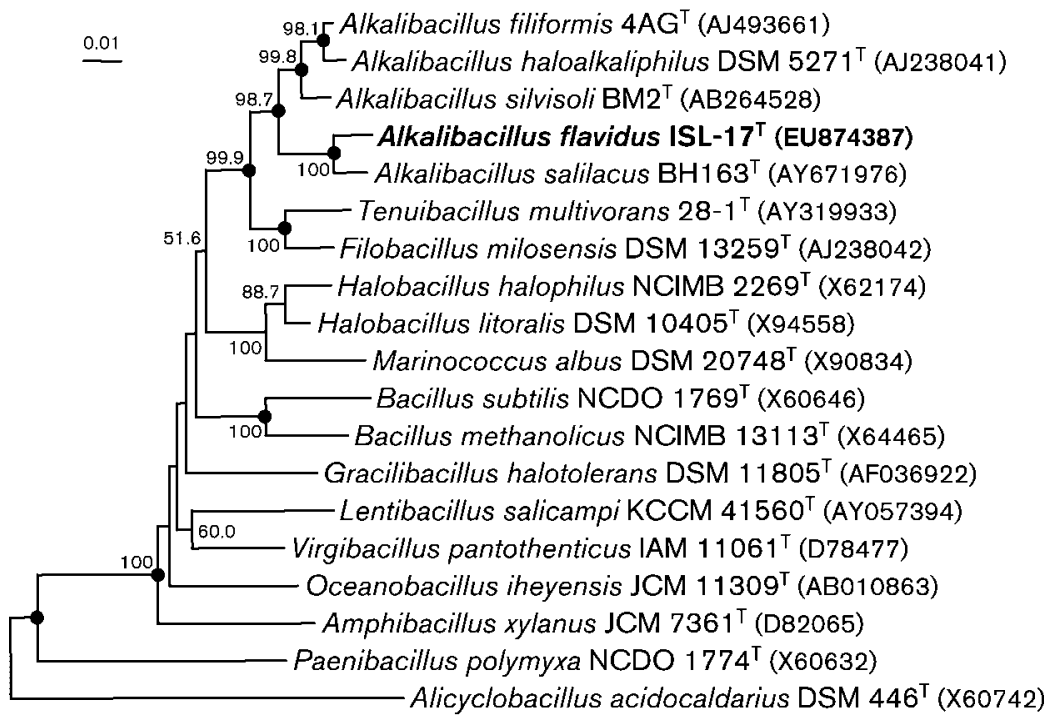

Fig. 1. Neighbour-joining phylogenetic tree
based on $16 \mathrm{~S}$ rRNA gene sequences showing
the positions of strain $I S L-17^{\top}$, Alkalibacillus
species and some other related taxa.
Bootstrap values (expressed as percentages
of 1000 replications) of $>50 \%$ are shown at
branch points. Filled circles indicate that the
corresponding nodes were also recovered in
trees generated with the maximum-likelihood
and maximum-parsimony algorithms. The
sequence of Alicyclobacillus acidocaldarius
DSM $446^{\top}$ was used as an outgroup. Bar,
0.01 substitutions per nucleotide position. 
Table 2. Cellular fatty acid compositions of strain ISL-17 $7^{\top}$ and A. salilacus KCTC $3916^{\top}$

Data from this study. Values are percentages of total fatty acids; fatty acids that represent $<0.5 \%$ in both strains have been omitted. - , Not detected.

\begin{tabular}{|c|c|c|c|}
\hline \multirow[t]{2}{*}{ Fatty acid } & \multicolumn{2}{|c|}{ Strain ISL-17 ${ }^{\mathrm{T}}$} & \multirow{2}{*}{$\begin{array}{c}\begin{array}{c}\text { A. salilacus } \\
\text { KCTC } 3916^{\mathrm{T}}\end{array} \\
30{ }^{\circ} \mathrm{C}\end{array}$} \\
\hline & $37^{\circ} \mathrm{C}$ & $30{ }^{\circ} \mathrm{C}$ & \\
\hline \multicolumn{4}{|l|}{ Straight-chain } \\
\hline $\mathrm{C}_{15: 0}$ & 4.0 & 2.4 & 0.4 \\
\hline $\mathrm{C}_{16: 0}$ & 0.6 & 0.6 & 1.1 \\
\hline \multicolumn{4}{|l|}{ Unsaturated } \\
\hline $\mathrm{C}_{16: 1} \omega 7 c$ alcohol & 0.3 & 1.5 & 1.2 \\
\hline \multicolumn{4}{|l|}{ Branched } \\
\hline iso- $\mathrm{C}_{14: 0}$ & 13.1 & 8.1 & 2.7 \\
\hline iso- $\mathrm{C}_{15: 0}$ & 25.1 & 27.2 & 26.8 \\
\hline anteiso- $\mathrm{C}_{15: 0}$ & 24.3 & 29.9 & 38.6 \\
\hline iso- $\mathrm{C}_{16: 0}$ & 25.2 & 19.8 & 9.9 \\
\hline iso- $\mathrm{C}_{17: 0}$ & 1.0 & 1.3 & 1.9 \\
\hline anteiso- $\mathrm{C}_{17: 0}$ & 5.4 & 7.9 & 15.6 \\
\hline \multicolumn{4}{|l|}{ Unknown } \\
\hline ECL 14.263 & - & 0.4 & 1.0 \\
\hline
\end{tabular}

port the result of the phylogenetic analysis, i.e. that strain ISL- $17^{\mathrm{T}}$ belongs to the genus Alkalibacillus.

Strain ISL- $17^{\mathrm{T}}$ exhibited a mean DNA-DNA relatedness value of $19 \%$ with respect to $A$. salilacus KCTC $3916^{\mathrm{T}}$, which had an $16 \mathrm{~S}$ rRNA gene sequence similarity value of greater than $97 \%$ to strain ISL- $17^{\mathrm{T}}$. Strain ISL- $17^{\mathrm{T}}$ was distinguishable from recognized Alkalibacillus species by differences in several phenotypic characteristics as listed in Table 1. The phylogenetic and genetic distinctiveness and differential phenotypic properties of strain ISL- $17^{\mathrm{T}}$ are sufficient to categorize it as a member of a species that is distinct from the four currently recognized Alkalibacillus species (Wayne et al., 1987; Stackebrandt \& Goebel, 1994). On the basis of the data presented, strain ISL $-17^{\mathrm{T}}$ is considered to represent a novel species of the genus Alkalibacillus, for which the name Alkalibacillus flavidus sp. nov. is proposed.

\section{Description of Alkalibacillus flavidus sp. nov.}

Alkalibacillus flavidus (fla'vi.dus. L. masc. adj. flavidus pale yellow).

Cells are rod-shaped $(0.2-0.4 \times 0.8-9.5 \mu \mathrm{m})$, but a few cells that are longer than $10.0 \mu \mathrm{m}$ do occur. Gram-stainpositive. Motile by means of peritrichous flagella. Terminal spherical endospores are observed in swollen sporangia. Colonies on $8 \% \mathrm{NaCl} \mathrm{MA}$ are circular, raised, glistening, smooth, light yellow in colour and 1.0-1.5 mm in diameter after incubation for 3 days at $37^{\circ} \mathrm{C}$. Optimal temperature for growth is $37^{\circ} \mathrm{C}$. Growth occurs at 10 (weak) and $55{ }^{\circ} \mathrm{C}$, but not at 4 or $60{ }^{\circ} \mathrm{C}$. Optimal $\mathrm{pH}$ for growth is between 8.5 and 9.0; growth occurs at pH 5.5 and 9.5, but not at $\mathrm{pH} 5.0$ or 10.0. Optimal growth occurs in the presence of approximately $10 \%(\mathrm{w} / \mathrm{v}) \mathrm{NaCl}$. Growth occurs in the presence of 4 and $26 \%(\mathrm{w} / \mathrm{v}) \mathrm{NaCl}$, but not in the presence of 3 or $27 \%(\mathrm{w} / \mathrm{v}) \mathrm{NaCl}$. Anaerobic growth does not occur on $8 \% \mathrm{NaCl} \mathrm{MA}$ or on $8 \% \mathrm{NaCl} \mathrm{MA}$ supplemented with potassium nitrate. Catalase- and oxidase-positive. Nitrate reduction is negative. Tweens 20, 40, 60 and 80 are hydrolysed, but aesculin, casein, gelatin, hypoxanthine, starch, tyrosine and xanthine are not. $\mathrm{H}_{2} \mathrm{~S}$ is not produced. Acid is produced from maltose and D-ribose, but not from L-arabinose, cellobiose, Dfructose, D-galactose, D-glucose, lactose, D-mannitol, Dmannose, melezitose, melibiose, raffinose, L-rhamnose, sucrose, trehalose, D-xylose, myo-inositol or D-sorbitol. Susceptible to ampicillin, carbenicillin, cephalothin, chloramphenicol, gentamicin, kanamycin, lincomycin, novobiocin, oleandomycin, penicillin $\mathrm{G}$ and streptomycin, but not to neomycin, polymyxin $\mathrm{B}$ or tetracycline. In assays with the API ZYM system, alkaline phosphatase, esterase (C4), esterase lipase (C8) and $\alpha$-glucosidase are present, but lipase (C14), leucine arylamidase, valine arylamidase, cystine arylamidase, trypsin, $\alpha$-chymotrypsin, acid phosphatase, naphthol-AS-BI-phosphohydrolase, $\alpha$-galactosidase, $\beta$-galactosidase, $\beta$-glucuronidase, $\beta$-glucosidase, $N$ acetyl- $\beta$-glucosaminidase, $\alpha$-mannosidase and $\alpha$-fucosidase are absent. The predominant menaquinone is MK-7. The major fatty acids ( $>10 \%$ of total fatty acids) are iso- $\mathrm{C}_{15: 0}$, anteiso- $\mathrm{C}_{15: 0}$ and iso- $\mathrm{C}_{16: 0}$.

The type strain is ISL- $17^{\mathrm{T}}$ (=KCTC $13258^{\mathrm{T}}=\mathrm{CCUG}$ $56753^{\mathrm{T}}$ ), isolated from a marine solar saltern of the Yellow Sea, Korea. The DNA G $+\mathrm{C}$ content of the type strain is $48.1 \mathrm{~mol} \%$ (determined by HPLC).

\section{Acknowledgements}

This work was supported by the 21C Frontier program of Microbial Genomics and Applications (grant MG05-0401-2-0) from the Ministry of Science and Technology (MOST) of the Republic of Korea.

\section{References}

Bruns, A., Rohde, M. \& Berthe-Corti, L. (2001). Muricauda ruestringensis gen. nov., sp. nov., a facultatively anaerobic, appendaged bacterium from German North Sea intertidal sediment. Int J Syst Evol Microbiol 51, 1997-2006.

Cowan, S. T. \& Steel, K. J. (1965). Manual for the Identification of Medical Bacteria. London: Cambridge University Press.

Ezaki, T., Hashimoto, Y. \& Yabuuchi, E. (1989). Fluorometric deoxyribonucleic acid-deoxyribonucleic acid hybridization in microdilution wells as an alternative to membrane filter hybridization in which radioisotopes are used to determine genetic relatedness among bacterial strains. Int J Syst Bacteriol 39, 224-229.

Fritze, D. (1996). Bacillus haloalkaliphilus sp. nov. Int J Syst Bacteriol 46, 98-101. 
Jeon, C. O., Lim, J.-M., Lee, J.-M., Xu, L.-H., Jiang, C.-L. \& Kim, C.-J. (2005). Reclassification of Bacillus haloalkaliphilus Fritze 1996 as Alkalibacillus haloalkaliphilus gen. nov., comb. nov. and the description of Alkalibacillus salilacus sp. nov., a novel halophilic bacterium isolated from a salt lake in China. Int J Syst Evol Microbiol 55, 1891-1896.

Komagata, K. \& Suzuki, K. (1987). Lipid and cell-wall analysis in bacterial systematics. Methods Microbiol 19, 161-207.

Lányí, B. (1987). Classical and rapid identification methods for medically important bacteria. Methods Microbiol 19, 1-67.

Leifson, E. (1963). Determination of carbohydrate metabolism of marine bacteria. J Bacteriol 85, 1183-1184.

Romano, I., Lama, L., Nicolaus, B., Gambacorta, A. \& Giordano, A. (2005). Alkalibacillus filiformis sp. nov., isolated from a mineral pool in Campania, Italy. Int J Syst Evol Microbiol 55, 2395-2399.

Sasser, M. (1990). Identification of bacteria by gas chromatography of cellular fatty acids, MIDI Technical Note 101. Newark, DE: MIDI Inc.

Stackebrandt, E. \& Goebel, B. M. (1994). Taxonomic note: a place for DNA-DNA reassociation and $16 \mathrm{~S}$ rRNA sequence analysis in the present species definition in bacteriology. Int J Syst Bacteriol 44, 846849.
Tamaoka, J. \& Komagata, K. (1984). Determination of DNA base composition by reversed-phase high-performance liquid chromatography. FEMS Microbiol Lett 25, 125-128.

Usami, R., Echigo, A., Fukushima, T., Mizuki, T., Yoshida, Y. \& Kamekura, M. (2007). Alkalibacillus silvisoli sp. nov., an alkaliphilic moderate halophile isolated from non-saline forest soil in Japan. Int J Syst Evol Microbiol 57, 770-774.

Wayne, L. G., Brenner, D. J., Colwell, R. R., Grimont, P. A. D., Kandler, O., Krichevsky, M. I., Moore, L. H., Moore, W. E. C., Murray, R. G. E. \& other authors (1987). International Committee on Systematic Bacteriology. Report of the ad hoc committee on reconciliation of approaches to bacterial systematics. Int J Syst Bacteriol 37, 463-464.

Yoon, J.-H., Kim, H., Kim, S.-B., Kim, H.-J., Kim, W. Y., Lee, S. T., Goodfellow, M. \& Park, Y.-H. (1996). Identification of Saccharomonospora strains by the use of genomic DNA fragments and rRNA gene probes. Int J Syst Bacteriol 46, 502-505.

Yoon, J.-H., Lee, S. T. \& Park, Y.-H. (1998). Inter- and intraspecific phylogenetic analysis of the genus Nocardioides and related taxa based on 16S rDNA sequences. Int J Syst Bacteriol 48, 187-194.

Yoon, J.-H., Kang, K. H. \& Park, Y.-H. (2003). Psychrobacter jeotgali sp. nov., isolated from jeotgal, a traditional Korean fermented seafood. Int J Syst Evol Microbiol 53, 449-454. 